\title{
Prokrastinasi Akademik Ditinjau dari Konsep Diri Mahasiswa Profesi Ners
}

\author{
${ }^{1}$ Briyan Priyono Wisnu Mukti, ${ }^{2}$ Hamid Mukhlis, ${ }^{3}$ Ikhwan Amirudin, ${ }^{4}$ Sutrisno \\ ${ }^{1234}$ Program Studi Ilmu Keperawatan Universitas Aisyah Pringsewu \\ e-mail: ${ }^{1}$ bronbrian701@gmail.com ${ }^{2}$ Hamid.Mukhlis@mail.ugm.ac.id ${ }^{3}$ nurse87ikhwan@gmail.com \\ thpecinta@gmail.com
}

\begin{abstract}
Abstrak. Pada saat mahasiswa ners melakukan praktik klinik di RSUD Dr. H. Abdol Moeloek Lampung dalam menyelesaikan tugas laporan asuhan keperawatan banyak yang melakukan penundaan untuk menyelesaikan sesuai target yang ditentukan oleh akademik, 8 dari 10 mahasiswa menyatakan sering menunda tugas saat menyusun laporan asuhan keperawatan. Penelitian ini bertujuan untuk mengetahui dan menguji secara empiris hubungan konsep diri dengan prokrastinasi pada mahasiswa ners yang sedang praktik di RSUD Abdoel Moeloek Lampung. Pengambilan sampel menggunakan teknik kuota sampling. Jumlah sampel dalam penelitian ini sebanyak 50 mahasiswa. Penelitian ini disusun berdasarkan skala likert dengan menggunakan skala Prokrastinasi Procrastination Assesment Scale For Student dan Skala konsep diri. Berdasarkan analisis data menggunakan uji Gamma, diperoleh hasil sebagai berikut: Ada hubungan negative antara konsep diri dengan prokrastinasi, diamana $r_{x y}=-0.565$ dengan signifikan $p=0.001<0.005$. Artinya hipotesis yang diajukan semakin tinggi konsep diri maka semakin rendah dinyatakan diterima.
\end{abstract}

Kata kunci: Prokrastinasi Akademik, Konsep Diri, Mahasiswa Profesi Ners

\begin{abstract}
When students practice clinical practice at the RSUD Dr. H. Abdol Moeloek Lampung in completing the tasks of nursing care reports that many postponed completing according to the targets set by the academic, 8 of 10 students stated that they often postpone assignments when compiling reports on nursing care. This study aims to identify and test empirically the correlation of self-concept and procrastination to student students who are practicing at Abdoel Moeloek Lampung Hospital. Sampling uses quota sampling technique. The number of samples in this study were 50 students. This research was arranged based on the Likert scale using the Procrastination Assessment Scale For Student scale and the self-concept scale. Based on data analysis using the Gamma test, the following results are obtained: There is a negative correlation between self-concept and procrastination, where is $r x y=-0.565$ with a significant $p=0.001<0.005$. This means that the hypothesis proposed is the higher the self esteem, the lower is declared acceptable.
\end{abstract}

Keywords: Academic Procrastination, Self Esteem, Profession Ners Student

\section{Pendahuluan}

Pendidikan keperawatan adalah pendidikan yang bersifat akademis profesional, yaitu mempunyai landasan akademik dan landasan profesi yang cukup. Sebagai lulusan pendidikan tinggi keperawatan yang diperoleh pada penerapan kurikulum pendidikan melalui berbagai bentuk pengalaman belajar. Sikap dan kemampuan professional lulusan ditumbuhkan dan dibina sepanjang proses pendidikannya melalui berbagai bentuk pengalaman belajar, salah satunya yaitu pengalaman belajar praktek. Bobot satu sks pengalaman belajar praktikum 
dijabarkan dalam kegiatan pembelajaran sama dengan 2-3 jam kegiatan pembelajaran per minggu dalam satu semester (Nursalam, 2011).

Pelaksanaan praktik klinik didukung dengan penerapan beberapa metode pembelajaran klinik, metode pembelajaran tersebut adalah pengelolaan kasus, konferensi klinik (pra dan post konferensi), bed side teaching, seminar kasus dan asuhan keperawatan, mahasiswa dibimbing oleh CI (clinical instructor) dari ruangan tempat mahasiswa melakukan praktik. Selain itu mahasiswa juga dibimbing oleh dosen dari pihak akademik (PSIK UR, 2016). Pada kenyataanya, tidak sedikit mahasiswa yang tidak mampu menjalankan praktik klinik dengan optimal, karena diawal sudah merasa terbebani, dan cenderung mengabaikan tanggung jawab yang harus dijalani (Mahdiyanto, 2011).

Menurut Omolayo dan Omole (2013), beban kerja berlebih mempengaruhi mekanisme koping individu dalam aktivitas yang dilakukan dan berdampak pada hasil kinerja dalam menyelesaikan tugasnya. Beban kerja tidak hanya berorientasi kepada tugas, juga berorientasi kepada konsep diri orang yang mengerjakannya. Penelitian Croxson (2017) menyatakan bahwa Mekanisme koping mempengaruhi bagaimana seseorang menilai diri sendiri. seseorang yang bertanggung jawab dalam mengelola beban kerja akan sering menggunakan koping yang inovatif sehingga mampu merancang tujuan-tujuan yang sesuai rencana.

Hasil penelitian Ghufron dan Risnawati (2012) menyatakan bahwa Presentase jenis-jenis tugas akademik yang di prokrastinasikan mahasiswa yaitu menulis $46 \%$, belajar untuk persiapan ujian 27,6\%, membaca $30,1 \%$, tugas administrative $10,6 \%$, menghadiri perkuliahan $23 \%$, aktivitas perkuliahan secara umum 10,2\% terhadap tugas akademik mahasiswa. Menurut Kartadinata \& Tjundjing (2008) di Amerika, mahasiswa melakukan penundaan atau prokrastinasi pada permulaan atau penuntasan tugas sebanyak $95 \%$ dan $70 \%$ mahasiswa menyatakan sering melakukannya. Sedangkan menurut penelitian Burka dan Yuen (2008) perkiraan prokrastinasi akademik yang terjadi di kalangan mahasiswa sebesar $75 \%$, dengan 50\% mahasiswa menyatakan bahwa prokrastinasi dilakukan secara konsisten dan menganggapnya sebagai suatu masalah.

Berdasarkan studi pendauluan yang dilakukan peneliti pada tanggal 23 Februari 2019 kepada 10 mahasiswa keperawatan profesi ners yang sedang menjalankan praktik di RSUD Abdul Moeloek Lampung, dalam menyelesaikan tugas laporan asuhan keperawatan banyak yang melakukan penundaan untuk menyelesaikan sesuai target yang ditentukan oleh akademik, 8 dari 10 mahasiswa menyatakan sering menunda tugas saat menyusun laporan asuhan keperawatan, sedangkan dua mahasiswa tidak. Empat orang mahasiswa mengatakan sering mengerjakan tugas secara deadline yang disebabkan karena banyaknya tugas lain sehingga mereka lebih memilih tugas yang lebih cepat dikumpulkan terlebih dahulu, sehingga tugas lain menjadi ditunda, dua mahasiswa mengatakan merasa kurang tidur dan waktu liburan mereka terganggu dikarenakan merasa terbebani terhadap banyaknya tugas-tugas akademik. Sedangkan dua orang mahasiswa menyatakan malas mengerjakannya (Mukhlis, 2016).

Atas rasionalisasi demikian, maka penelitian ini dilaksanakan untuk menilai konsep diri pada mahasiswa Keperawatan Ners di Rumah Sakit Umum Daerah Dr. H. Abdul Moeloek provinsi Lampung. Penelitian ini juga bermanfaat sebagai media untuk memperbaiki konsep diri akademik pada mahasiswa Keperawatan Ners Universitas Aisyah Pringsewu.

Tujuan Penelitian ini adalah mengetahui hubungan antara konsep diri dengan prokrastinasi akademik mahasiswa Ners, mengetahui distribusi frekuansi tingkat konsep diri pada mahasiswa Ners, dan mengetahui distribusi frekuensi tingkat kejadian Prokrastinasi Akademik pada mahasiswa Ners. 


\section{Metode}

Jenis penelitian yang digunakan dalam penelitian ini adalah kuantitatif, Penelitian kuantitatif adalah suatu proses menemukan pengetahuan yang menggunakan data berupa angka sebagai alat untuk menganalisis keterangan mengenai apa yang ingin diketahui. Dalam pendekatan kuantitatif hakekat hubungan diantara variabel-variabel dianalisis dengan menggunakan teori yang obyektif (Notoatmodjo, 2010). Penelitian ini dilakukan pada bulan Maret 2019 di RSUD Dr. H. Abdul Moeloek Lampung.

Dalam penelitian ini populasi yang diteliti adalah mahasiswa program studi Keperawatan profesi Ners di RSUD Dr. H. Abdul Moeloek Lampung yang berjumlah 250 Mahasiswa dari empat institusi di Lampung yaitu Universitas Mitra Lampung, Universitas Malahayati, Universitas Aisyah Pringsewu, STIKes Muhammadiyah Pringsewu.

Teknik pengambilan sampel dalam penelitian ini menggunakan quota sampling yaitu teknik pengambilan sampel dengan cara menetapkan jumlah tertentu sebagai target yang harus dipenuhi dalam pengambilan sampel dari populasi, kemudian dengan patokan jumlah tersebut peneliti mengambil sampel secara sembarang asal memenuhi persyaratan sebagai sampel dari populasi tersebut. Teknik ini jumlah populasi di klasifikasikan dalam beberapa kelompok. Pengambilan sampel dengan menetapkan jumlah subjek 50 mahasiswa Ners yang akan di teliti.

Data yang dikumpulkan dalam penelitian ini adalah data primer. Data primer, yaitu hasil kuesioner prokrastinasi akademik Procrastination Assesment Scale For Student (PASS) yang disusun oleh Solomon \& Rothblum (1984) dan kuisioner konsep diri yang dikembangkan oleh Coopersmith (1976). Jenis data yang dikumpulkan adalah data kuantitatif yang berupa angka atau presentase. Cara pengumpulan data menggunkan instrumen yang digunkan dalam penelitian ini.

Analisis data dilakukan untuk mengetahui distribusi frekuensi dari sub variabel yang diamati sehingga dapat mengetahui gambaran dari variabel yang diamati sehingga dapat mengetahui gambaran dari variabel yang ditelliti (Notoatmodjo, 2010). Uji statistic menggunakan Gamma, yaitu uji statistik yang di tunjukkan untuk mengetahui hubungan antara dua variabel atau lebih berskala ordinal (Sopiyudin, 2014).

\section{Hasil Penelitian}

Tabel 1. distribusi frekuensi konsep diri pada mahasiswa ners di RSUD Abdul Moeloek

\begin{tabular}{lcc}
\hline \multicolumn{1}{c}{ Rentang nilai } & Frekuensi & Persentase (\%) \\
\hline $85-112$ (positif) & 21 & 42 \\
$54-84$ (sedang) & 29 & 58 \\
$28-53$ (negatif) & 0 & 0 \\
\hline
\end{tabular}

Berdasarkan tabel 1 dari 50 responden, terdapat 21 responden (42\%) memiliki konsep diri positip dan sisanya terdapat 29 responden (58\%) memiliki konsep diri yang sedang.

Tabel 2 distribusi frekuensi kejadian prokrastinasi akademik pada mahasiswa ners

\begin{tabular}{lcc}
\hline \multicolumn{1}{c}{ Rentang nilai } & Frekuensi & Persentase \\
\hline $61-80$ (Tinggi) & 1 & $2 \%$ \\
$40-60$ (sedang) & 28 & $56 \%$ \\
$20-39$ (rendah) & 21 & $42 \%$ \\
\hline
\end{tabular}


Berdasarkan tabel 4.3 diatas bahwa dari 50 subjek, terdapat 21 subjek memiliki prokrastinasi yang masuk ke dalam kategori rendah $42 \%$, kategori sedang $56 \%$ dan kategori tinggi $2 \%$.

Hasil penelitian yang dilakukan pada 50 sampel mahasiswa Ners yang sedang praktik di RSUD Dr. H. Abdul Moeloek Lampung. Berdasarkan hasil analisa data yang diperoleh hasil uji Gamma pada penelitian ini didapatkan nilai sebesar 0.565; $\mathrm{p}=0.001(\mathrm{p} \varangle 0.05)$. hal ini menunjukkan bahwa ada pengaruh signifikan dari konsep diri terhadap prokrastinasi akademik.

\section{Pembahasan}

Hasil penelitian yang dilakukan pada tingkat konsep diri dengan 50 sampel mahasiswa Ners yang sedang praktik di RSUD Dr. H. Abdul Moeloek Lampung di dapatkan hasil sebesar 42\% (21 responden) yang mempunyai konsep diri positif dan 58\% (29 responden) yang mempunyai konsep diri sedang. Sejalan dengan penelitian marvel (2013) subjek dengan kategori self esteem sangat rendah sebanyak 4 orang $(3,4 \%)$, kategori self esteem rendah sebanyak 13 orang $(11 \%)$, kategori self esteem cenderung rendah sebanyak 38 orang $(32,2 \%)$, kategori self esteem cenderung tinggi sebanyak 45 orang $(38.1 \%)$, kategori self esteem tinggi sebanyak 16 orang $(13,6 \%)$, dan kategori self esteem sangat tinggi sebanyak 2 orang $(1,7 \%)$.

Menurut Hurlock (1979 dalam ghufron dan Risnawita, 2012) menyatakan bahwa konsep diri dapat membuat mahasiswa lebih yakin akan kemampuan dirinya sehingga dapat menyelesaikan tugas yang menjadi tanggungjawabnya sebagai mahasiswa, tidak membuang waktu dalam mengerjakan tugas yang diberikan dan segera menyelesaikan tugas tersebut. Ketika seorang mahasiswa mengalami situasi yang tidak menyenangkan dalam dirinya, maka dengan adanya konsep diri akan menentukan seseorang dalam bertindak, berfikir, dan bereaksi sewaktu menghadapi situasi-situasi yang tidak menyenangkan.

Responden yang memiliki konsep diri rendah berhubungan dengan harapan yang rendah pada tugas akademiknya. Apabila individu merasa kurang mampu dan percaya diri, maka akan muncul harapan yang rendah pada individu untuk berhasil.

Hasil penelitian yang dilakukan pada tingkat prokrastinasi akademik dengan 50 sampel mahasiswa Ners yang sedang praktik di RSUD Dr. H. Abdul Moeloek Lampung di dapatkan hasil sebesar $2 \%$ (1 responden) dengan prokrastinasi akademik tinggi, 56\% (28 responden) dengan prokrastinasi sedang dan 42\% (21 responden) dengan prokrastinasi rendah.

Hasil penelitian Marvel (2013) menunjukkan Subjek dengan kategori prokrastinasi akademik sangat rendah 1 orang $(0.8 \%)$. Subjek dengan kategori prokrastinasi akademik rendah sebanyak 16 orang (13.6\%). Subjek dengan kategori prokrastinasi akademik cenderung rendah sebanyak 35 orang $(29.7 \%)$. Subjek dengan kategori prokrastinasi akademik cenderung tinggi sebanyak 46 orang (39.0\%). Subjek dengan kategori prokrastinasi akademik tinggi sebanyak 18 orang (15.3\%). Subjek dengan kategori prokrastinasi akademik sangat tinggi sebanyak 2 orang $(1.7 \%)$.

Hasil penelitian yang dilakukan pada 50 sampel mahasiswa Ners yang sedang praktik di RSUD Dr. H. Abdul Moeloek Lampung. Berdasarkan hasil analisa data yang diperoleh hasil uji Gamma pada penelitian ini didapatkan nilai sebesar 0.565; $\mathrm{p}=0.001(\mathrm{p} \varangle 0.05)$. hal ini menunjukkan bahwa ada pengaruh signifikan dari konsep diri terhadap prokrastinasi akademik. Hal ini menunjukkan bahwa semakin positif konsep diri subjek maka akan semakin rendah prokrastinasi akademiknya. Konsep diri 
mempunyai sumbangan efektif terhadap prokrastinasi akademik mahasiswa sebesar $42 \%$ sementara sisanya $58 \%$ dipengaruhi oleh faktor lain.

Dari hasil penelitian Syifa, L., Sunawan dan Nusantoro, E. (2018) dalam penelitiannya yang berjudul "prokrastinasi akademik pada lembaga kemahasiswaan dari segi konsep diri dan regulasi emosi" hasil penelitian menunjukkan bahwa antara konsep diri dan prokrastinasi akademik memiliki hubungan yang signifikan $(\mathrm{R}=0.394, \mathrm{~F}(4,164)=7,527, \mathrm{P}=<0.01)$, kemudian antara regulasi emosi dan prokrastinasi akademik juga memiliki hubungan yang signifikan $(\mathrm{R}=0.129, \mathrm{~F}(3.161)=8.756 \mathrm{P}=<0.01$.

Berdasarkan penelitian Selan, M., A (2017) yang berjudul "Hubungan konsep diri dengan prokrastinasi akademik siswa pada siswa kelas VII di SMP Kristen Sendang Kabupaten Tulungagung tahun pelajaran 2015/2016" menggunakan hasil uji $\mathrm{r}$ product moment diperoleh hasil hitung $=0.621$ sedangkan $\mathrm{r}$ tabel pada taraf signifikan $0.05 \%$ (untuk $\mathrm{db}=33$ ) adalah 0.344 maka dapat diputuskan bahwa : $r$ hitung $\geq \mathrm{r}$ tabel $(0.621>0.344)$ pada taraf signifikan $0.05 \%$, yang berarti hipotesis alternatif $(\mathrm{Ha})$ yang berbunyi ada hubungan konsep diri dengan prokrastinasi akademik siswa kelas VII di SMP Kristen Sendang Kabupaten Tulungagung tahun pelajaran 2015/2016, dinyatakan dapat diterima. Dengan demikian bahwa anggapan hubungan konsep diri dengan prokrastinasi akademik memiliki hubungan searah yang terbukti kebenarannya, pembuktian tersebut sejalan dengan gagasan Calhoun dan Acocella (1995, dalam Ghufron dan Risnawita, 2012) bahwa ciri seorang yang memiliki konsep diri positif terdiri dari pengetahuan tentang dirinya sendiri, pengharapan diri, penilaian terhadap diri sendiri dan dapat menerima dengan baik. Hal ini menunjukkan bagaimana kita melihat diri kita sendiri dan yakin terhadap potensi yang dimilikinya sehingga menimbulkan sikap percaya akan apa yang akan dilakukan dan merasa bahwa dirinya memiliki potensi tersebut.

Hasil observasi peneliti menemukan tingkat prokrastinasi akademik yang tinggi dapat disebabkan oleh beberapa faktor perceived ability dimana tidak yakin terhadap kemampuan dirinya dan takut akan kegagalan. Faktor intention action juga berpengaruh karena seorang yang melakukan prokrastinasi kesulitan melakukan sesuatu sesuai dengan batas waktu dan kesenjangan waktu antara rencana sendiri serta kinerja aktual. Menurut harriot (2011) seseorang yang melakukan prokrastinasi tidak bermaksud untuk menghindari atau tidak mau tahu dengan tugas yang di hadapi. Akan tetapi mereka hanya menunda-nunda untuk mengerjakannya, sehingga menyita waktu yang dibutuhkan untuk menyelesaikan tugasnya. Penundaan tersebut menyebabkan dia gagal dalam menyelesaikan tugasnya tepat waktu. Prokrastinasi merupakan kebiasaan penundaan yang tidak bertujuan dan proses penghindaran waktu, yang hal itu sebenarnya tidak perlu dilakukan seseorang karena adanya ketakutan untuk gagal, serta adanya pandangan bahwa segala sesuatu dilakukan dengan benar. Penundaan yang telah menjadi respon tetap atau kebiasaan dapat dipandang sebagai suatu perilaku prokrastinasi.

\section{Kesimpulan dan Saran}

Kesimpulan akhir yang telah diperoleh dari penelitian ini bahwa konsep diri berhubungan secara signifikan dengan prokrastinasi akademik mahasiswa. Semakin tinggi tingkat konsep diri mahasiswa, maka akan semakin rendah tingkat prokrastinasi akademiknya. Sebaliknya semakin rendah tingkat konsep diri mahasiswa maka akan semakin tinggi tingkat prokrastinasi akademiknya. 
Untuk penelitian selanjutnya mengenai Prokrastinasi Akademik lebih fokus kepada faktor perceived ability dimana tidak yakin terhadap kemampuan dirinya dan takut akan kegagalan dan Faktor intention action juga berpengaruh karena seorang yang melakukan prokrastinasi kesulitan melakukan sesuatu sesuai dengan batas waktu dan kesenjangan waktu antara rencana sendiri serta kinerja aktual untuk diteliti lebih lanjut.

\section{Daftar Pustaka}

Dahlan, S. (2010). Besar Sampel dan Cara Pengambilan Sampel. Jakarta : Salemba Medika.

Dahlan, S. (2016). Besar Sampel dalam Penelitian Kedokteran dan Kesehatan. Jakarta : Epidemologi Indonesia.

Hardono, et. Al. (2018). Pedoman Penulisan Tugas Akhir Mahasiswa. Pringsewu: Unit Penerbit dan Publikasi Aisyah.

Ghufron \& Risnawita. (2012). Teori-Teori Psikologi. Jogjakarta : Ar-Ruz Media.

Notoatmodjo, S. (2010). Metodologi Penelitian Kesehatan. Ed. Rev. Jakarta : Rineka Cipta.

Santrock, J.W. (2009). Psikologi Pendidikan Edisi II. Jakarta : Prana Media.

Sunaryo. (2013). Psikologi untuk Keperawatan. Jakarta : EGC

Fatimah, S. (2018). Menurunkan Prokrastinasi Akademik Melalui Penerapan Teori Hierarki Kebutuhan Maslow. IKIP Siliwangi Vol. 2, No. 1. Diakses pada 28 Oktober 2018.

Syifa, L., Sunawan \& Eko, N. (2018). Prokrastinasi Akademik pada Lembaga Kemahasiswaan dari Segi Konsep Diri dan Regulasi Emosi. Jurusan Bimbingan dan Konseling, Fakultas Ilmu Pendidikan, Universitas Negeri Semarang. Diakses pada 11 November 2018.

Mukhlis, H. (2016). Pelatihan Kebersyukuran; Sebuah Upaya untuk Menghadapi Ujian Nasional pada Siswa SMA. Jurnal Aisyah : Jurnal Il urunkan Kecemasan doi:https://doi.org/10.30604/jika.v1i1.3

Muyana, S. (2018). Prokrastinasi Akademik di Kalangan Mahasiswa Program Studi Bimbingan dan Konseling. Counsellia : jurnal Bimbingan dan Konseling Vol. 8, No. 1 Hal 45-52. Diakses pada 11 November 2018.

Selan, M.A. (2017). Hubungan Konsep Diri dengan Prokrastinasi Akademik Siswa pada Siswa Kelas VII di SMP Kristen Sendang Kabupaten Tulungagung Tahun Pelajaran 2015/2016. Bimbingan dan Konseling, Fakultas Keguruan Ilmu Pendidikan, Universitas Nusantara PGRI Kediri. Diakses pada 31 Maret 2019.

Rahmawati, S. (2017). Motivasi Berprestasi dan Prokrastinasi Akademik Mahasiswa. Jurnal Psiko Utama Vol. 5, No. 2 Hal 60-73. Diakses pada 10 November 2018.

Jatikusumo, M.R. (2016). Tingkat Prokrastinasi Akademik Mahasiswa. Program Studi Bimbingan dan Konseling Jurusan Ilmu Pendidikan, Fakultas Keguruan dan Ilmu Pendidikan, Universitas Sanata Dharma Yogyakarta. Diakses tanggal 03 April 2019.

Samaedam, S. (2016). Hubungan Harga Diri dan Konsep Diri dengan Prokrastinasi Akademik pada Siswa Kelas III Sekolah Ma'had Al-Muhammadiyah Thailand Selatan. Fakultas Psikologi Universitas Islam Negeri Maulana Malik Malang. Diakses pada 31 Maret 2019.

Dany, Carolina \& Rahmawati. (2016). Hubungan antara Konsep Diri Akademik, Efikasi Diri Akademik, Harga 
Diri, dan Prokrastinasi akademik pada siswa SMP di Kota Malang. Jurnal Kajinn Rimbingan dan Konseling Vol. 1, No. 2 Hal 60-67. Diakses pada 10 Novemver 2018.

Nurwahyuni, I. (2015). Hubungan Konsep Diri dan Interaksi Teman Sebaya dengan Prokrastinasi Akademik Mahasiswa. Program Magister Psikologi, Sekolah Pasca Sarjana, Universitas Muhammadiyah Surakarta. Diakses pada 06 februari 2019.

Fauziah,H.H. (2015). Faktor-Faktor yang Mempengaruhi Prokrastinasi Akademik pada Mahasiswa Fakultas Psikologi UIN Sunan Gunung Djati Bandung. Psympatic, Jurnal Ilmiah Psikologi Vol. 2, No. 2, Hal 123132. Diakses pada 11 November 2018.

Astuti, R.D. (2014). Identifikasi Faktor-Faktor yang Mempengaruhi Konsep Diri Siswa Sekolah Dasar Negeri Mendungan I Yogyakarta. Program Studi PGSD, Jurusan Pendidikan Pra Sekolah dan Sekolah Dasar, Fakultas Ilmu Pendidikan, Universitas Negeri Yogyakarta. Diakses pada 06 februari 2019.

Melina, M.R. (2014). Hubungan antara Konsep Diri dengan Prokrastinasi Akademik pada Mahasiswa Universitas Gunadarm. Fakultas Psikologi Universitas Gunadarma. Diakses pada 20 Februari 2019.

Sandra, K.I., Djalali, M.A., (2013). Manajemen Waktu, Efikasi Diri dan Prokrastinasi. Persona, Jurnal Psikologi Indonesia Vol.2, No.3, Hal 217-222. Diakses pada 10 Oktober 2018.

Ursia, N.R., Siaputra, I.D., \& Sutanto, N. (2013). Prokrastinasi Akademik dan Self-Control pada Mahasiswa Skripsi Fakultas Psikologi Universitas Surabaya. Makara Seri Sosial Humaniora, 17 (1). Diakses pada 10 oktober 2018.

Suharnan \& Handayani. (2012). Konsep Diri, Stress, dan Prokrastinasi Akademi ' la Mahasiswa. Persona, Jurnal Psikologi Indonesia Vol. 1, No. 2, Hal 144-121. Diakses pada 10 Nove.... _. 2018.

Zamroni. (2010). Pengaruh Konsep Diri dan Zuhud dan Motivasi Berprestasi Santri Pesantren Tebuireng Jombang. Fakultas Psikologi Universitas Islam Negeri Maulana Ibrahim Malang. Diakses pada 10 oktober 2018.

Steel, P. (2010). Arousal, Avoidant and Decisional Procrastinators :Do They Exist? Personality and Individual Differences, 48, 926-934.

Kartadinata, I., \& Tjundjing, S. (2008). I Love You Tomorrow : Prokrastinasi Akademik dan Manajemen Waktu. Anima, Indonesian Psychological Journal Vol. 23, No. 2, Hal 109-119. Diakses pada 27 Oktober 2018.

Burka, J.B., \& Yuen, L.M. (2008). Procrastination: Why You Do It.What to Do About It (New York : Perseus Books).

Solomon, L.J., \& Rothblum, E.D. (1984). Academic Procrastinotion : Frequency and Cognitive-Behavioral Correlates. Journal of Counseling Psychology,31.hal 503-509. 